\title{
THE HAEMAGGLUTINATION REACTION IN TUBERCULOSIS
}

\author{
BY \\ G. R. F. HILSON AND S. D. ELEK \\ From the Department of Bacteriology, St. George's Hospital Medical School, London
}

(RECEIVED FOR PUBLICATION SEPTEMBER 5, 1950)

Circulating antibodies reacting with tubercle bacilli or their extracts have been demonstrated repeatedly in the sera of patients suffering from pulmonary and other forms of tuberculosis. In a review of the subject Wilson and Miles (1946) suggest that a test based on the agglutination of tubercle bacilli is unreliable and that the precipitin test made by mixing the patient's serum with tuberculin is of no practical importance. The complement fixation test in the hands of various workers gave positive results in from 38 to $90 \%$ of patients with different forms of the disease, but it is also positive in from 10 to $15 \%$ of healthy persons and in those suffering from syphilis, leprosy, and malaria.

Middlebrook and Dubos (1948) showed that sheep's red cells suitably treated with an extract of the $\mathrm{H} 37$ strain of Myco. tuberculosis were agglutinated by the sera of six rabbits immunized with the B.C.G. strain; titres up to 1,280 were obtained. The cells were also agglutinated by the sera of six patients with active tuberculosis of the lungs to titres of 8 or over, and one patient with miliary disease gave a titre of 256. The sera of two Mantoux-negative nurses agglutinated the cells to a titre of 4 ; the cells were not agglutinated by miscellaneous antibacterial sera with the exception of a pneumococcus type XIV antiserum, which reacted only to a titre of under 32. Wassermann-positive sera did not react with the cells. A specimen of "old tuberculin" was also found to be capable of sensitizing sheep's red cells in a similar way, and therefore it appeared that at least one component of the "antigen" was heat stable. Evidence was also presented that the sensitizing substance or substances might be associated with the polysaccharide fraction of the bacillary extract. The same technique was used by Gernez-Rieux and Tacquet (1949), who examined the sera of 95 tuberculous patients and 43 controls. Of the tuberculous patients $80 \%$ gave titres of 8 and over, while $30 \%$ of the controls gave titres of 2 or 4 but none of 8 or over. With minor modifications the method has been tested by various workers. Sohier (1950) used a purified tuberculin for the sensitization of red cells. He appears to have obtained satisfactory results with tuberculous sera, but found false positives in his control series. He mentioned the use of human cells instead of sheep cells for the test, but did not carry out large-scale investigations. Smith and Scott (1950) used Lederle tuberculin concentrated four times for the sensitization of sheep's cells and found that $80 \%$ of 104 tuberculous patients gave positive reactions at titres of 2 and 
upwards ; three out of 62 tuberculin-negative controls gave positive results. They also tested the sera of 58 students before Mantoux testing. Of these $21 \%$ gave positive results. After Mantoux testing the sera of the students were re-examined, and this time $49 \%$ of them were found to be positive. They concluded that the test was mainly positive in active tuberculosis. Rothbard, Dooneief, and Hite (1950) examined 168 sera from patients with active tuberculosis. Of these $92.3 \%$ were positive at titres of 8 and over. None of 216 control sera was positive at that level. Of the control sera, however, $6 \%$ gave agglutination at lower titres.

For the purposes of the present investigation it was thought that the use of human Group O red cells, preferably Rh-negative, instead of sheep's cells, would simplify the technique since inactivation and absorption of the individual sera would no longer be necessary. The incidence of natural anti-O agglutinins in human sera is estimated to be of the order of $1: 1,000$ (Wiener, 1943); this remote contingency was covered by the use of a single control tube in which unsensitized cells were mixed with the highest concentration of the serum employed. Other modifications included the use of a lightly buffered saline solution as a diluent for the sensitizing agents tested and for the washing and dilution of the red cells in order to maintain the reaction of the various reagents approximately neutral. Chown's capillary tube method (Discombe and Meyer, 1948), adapted to a quantitative estimation of the haemagglutinative titre of patients' sera, was found to be most serviceable and economical in glassware and labour.

\section{Methods}

Buffered Saline.-Solution (a): $10.207 \mathrm{~g}$. of anhydrous potassium dihydrogen phosphate were dissolved in $500 \mathrm{ml}$. of distilled water.

Solution (b): $53.73 \mathrm{~g}$. of anhydrous disodium phosphate were dissolved in 1 litre of distilled water.

Then $389 \mathrm{ml}$. of solution (a) were added to $611 \mathrm{ml}$. of solution (b) to make 1 litre of isotonic $0.15 \mathrm{M}$ buffer, $p \mathrm{H}$ 7.0. One volume of this buffer was then mixed with 9 volumes of saline ( $0.9 \%$ sodium chloride), giving a final molar concentration of buffer of 0.015 .

Preparation of Sensitizing Agents.-Those used were "crude carbohydrate fraction," glycerol extracts, and tuberculin P.P.D.

“Old Tuberculin."-Burroughs Wellcome " old tuberculin" was used, and was found to have a $p \mathrm{H}$ of 8.4 and to be hypertonic, containing $5.13 \mathrm{~g}$. of sodium chloride per $100 \mathrm{ml}$. It was therefore diluted before use by the addition of 5 volumes of distilled water, the reaction being adjusted to $p \mathrm{H} 7.0$ with $\mathrm{N} / 1$ hydrochloric acid; $10 \mathrm{ml}$. of this mixture were used for the treatment of $0.5 \mathrm{ml}$. packed red cells.

"Crude Carbohydrate Fraction" (C.C.F.).-A partial fractionation of three different "old tuberculins" was carried out in order to produce protein-free solutions of polysaccharide for the sensitization of red cells. The method was similar to that described by Wieghard and Julianelle (1935) for preparing staphylococcal polysaccharides.

Tuberculin, $10 \mathrm{ml}$., was mixed with $10 \mathrm{ml}$. of distilled water and $20 \mathrm{ml}$. of $50 \%$ trichloracetic acid were added. The mixture was well shaken and allowed to stand about one hour until the precipitate became flocculent. The latter was separated by centrifugation and the clear brownish supernatant mixed with 6 volumes of $95 \%$ commercial ethanol which had been saturated with sodium acetate. This mixture was well shaken, stood for an hour in the cold, and the granular white precipitate filtered 
off or centrifuged. The precipitate was dissolved in the minimum amount of distilled water (about $2 \mathrm{ml}$.) and tested for the presence of protein by the addition of a little $50 \%$ trichloracetic acid: none was found at this stage in any batch. The watery solution was again mixed with 6 volumes of ethanol, the resulting precipitate spun down in a $50-\mathrm{ml}$. centrifuge tube, shaken with $40 \mathrm{ml}$. of acetone, recentrifuged, and the supernatant liquid discarded. The average dry yield from $10 \mathrm{ml}$. of old tuberculin was about $0.09 \mathrm{~g}$. For use in the tests the precipitate was not dried, but was dissolved in $20 \mathrm{ml}$. of buffered saline and gently warmed until the smell of acetone had gone. A quantity of $10 \mathrm{ml}$. of this colourless opalescent liquid was used for the treatment of $0.5 \mathrm{ml}$. of packed red cells.

The tuberculins from which these crude fractions were obtained were (a) Burroughs Wellcome "old tuberculin," derived from the human strain H $37 \mathrm{Rv}$; (b) Evans "old tuberculin " from N.C.T.C. 276 (human) ; (c) Evans " old tuberculin " from N.C.T.C. 913 (bovine).

The fractions from these different strains appeared similar in behaviour and were all capable of sensitizing human red cells. Most of the work was done with the fraction obtained from (a) and will be referred to as C.C.F. (H 37).

Glycerol Extracts.-Bulk lots of tubercle bacilli, grown on the surface of a fluid synthetic medium at $37^{\circ} \mathrm{C}$. for ten weeks and killed by steaming for three hours, were obtained as a by-product from the manufacture of "Weybridge P.P.D. tuberculin" (Green, 1946). One hundred grammes (moist weight) of bacilli were added to a flask containing 1 litre of a $5 \%$ solution of glycerol in distilled water; the flask was then heated at $100^{\circ} \mathrm{C}$. until the contained fluid had evaporated down to a volume of $100 \mathrm{ml}$. A portion of the grumous mixture resulting from this concentration was diluted with an equal volume of distilled water, and to this mixture an equal volume of $50 \%$ trichloracetic acid added. This mixture was shaken, allowed to stand for 15 minutes, and centrifuged; the deposit consisted of undissolved organisms and precipitated protein. The supernatant liquid was mixed with $95 \%$ commercial ethanol and the rest of the process described under the heading " crude carbohydrate fraction " carried out, in order to obtain a carbohydrate fraction comparable to that from the commercial "old tuberculins."

Four strains were treated in this way, a separate extract being made from each strain. They were human strains "DT," "PN," and "C" (Bureau of Animal Industry, Washington, U.S.A.), and an avian strain.

Tuberculin P.P.D.-The diagnostic tablets of tuberculin P.P.D. Parke Davis used for intradermal Mantoux testing were dissolved in $2 \mathrm{ml}$. of buffered saline to give a concentration of $0.001 \mathrm{~g}$. per ml., and this solution was used for the sensitization of $0.1 \mathrm{ml}$. of packed red cells for the testing of a small number of sera.

Sensitization of Red Cells.-Ten ml. of citrated human Group O Rh-negative (D -) blood were placed in a 30-ml. screw-cap universal container and the red cells spun down. The supernatant plasma was removed, and the cells washed three times with $20-\mathrm{ml}$. quantities of buffered saline. These centrifugations were done in an angle centrifuge at 2,000 r.p.m. for five minutes. Half a millilitre of the packed red cells was pipetted into a centrifuge tube containing $10 \mathrm{ml}$. of the sensitizing agent, and mixed by inversion two or three times. The mixture was incubated in the water bath at $37^{\circ} \mathrm{C}$. tor two hours, being mixed at intervals. The cells were then spun down, the supernatant discarded, and the cells washed again three times to remove all traces of the sensitizing substance in the suspending fluid. The packed cells from the third washing were mixed with four times their volume of buffered saline to give just over $2 \mathrm{ml}$. of a roughly $20 \%$ suspension, sufficient to test about 50 sera. 
A $20 \%$ suspension of unsensitized cells was also made for use as a control in the testing of each serum.

Agglutination appeared to be most rapid and clear-cut when the citrated human blood used for the preparation of cell suspensions was kept no longer than three weeks in the refrigerator, and when the sensitized cells were used immediately after they had been prepared. Sensitized cells kept in the cold for one night and washed once before use gave satisfactory results, but after this time were discarded. Red cells from four individuals were used, and no differences in their reactions were observed.

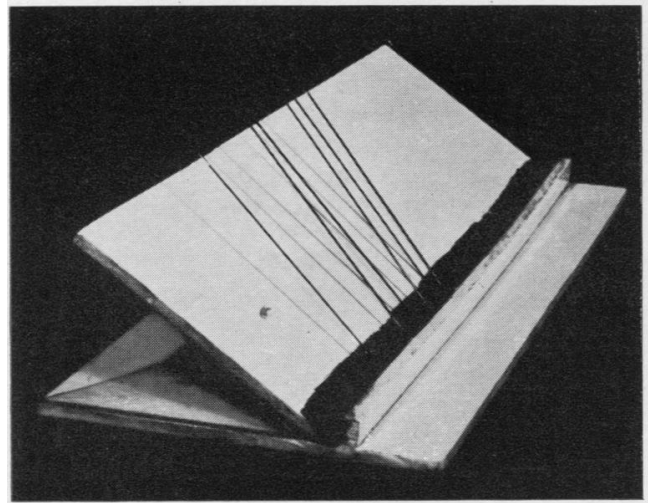

Fig. 1 $a .-$ The holder upright.

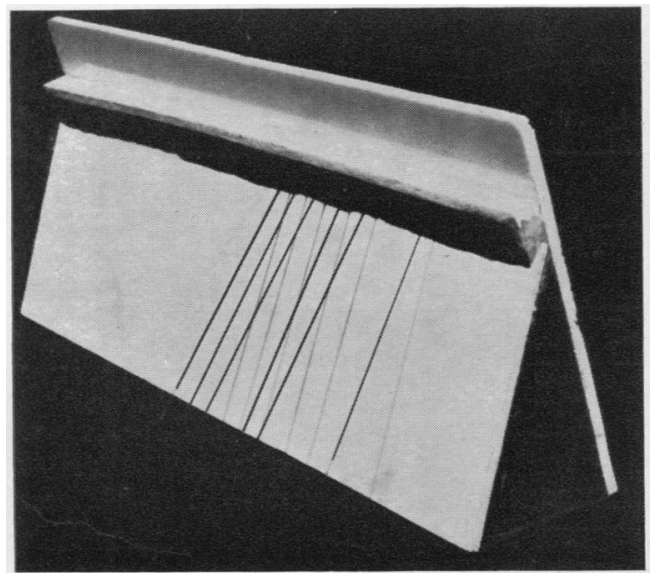

FIG. 1b.-The holder inverted.

Fig. 2.-Appearances of the completed test in two sera. The set of five tubes on the left shows agglutination in the first three tubes $(1: 2=$ $++, 1: 4=++, 1: 8=+, 1: 16=$ negative). Control tube is negative. The set on the right is negative in all five tubes.
Testing of Sera.-Doubling dilutions in buffered saline of about $0.2 \mathrm{ml}$. of serum were made on a glazed china blood-grouping tile, starting with $1: 2$ and ending with $1: 16$. Sera agglutinating to a titre of 16 were usually retested in higher dilutions. Batches of three sera could thus be diluted on a single tile.

Testing was carried out by Chown's capillary method as described by Discombe and Meyer (1948) using capillary tubes $10 \mathrm{~cm}$. long with a bore of 0.4 to $0.7 \mathrm{~mm}$. For each serum, a capillary

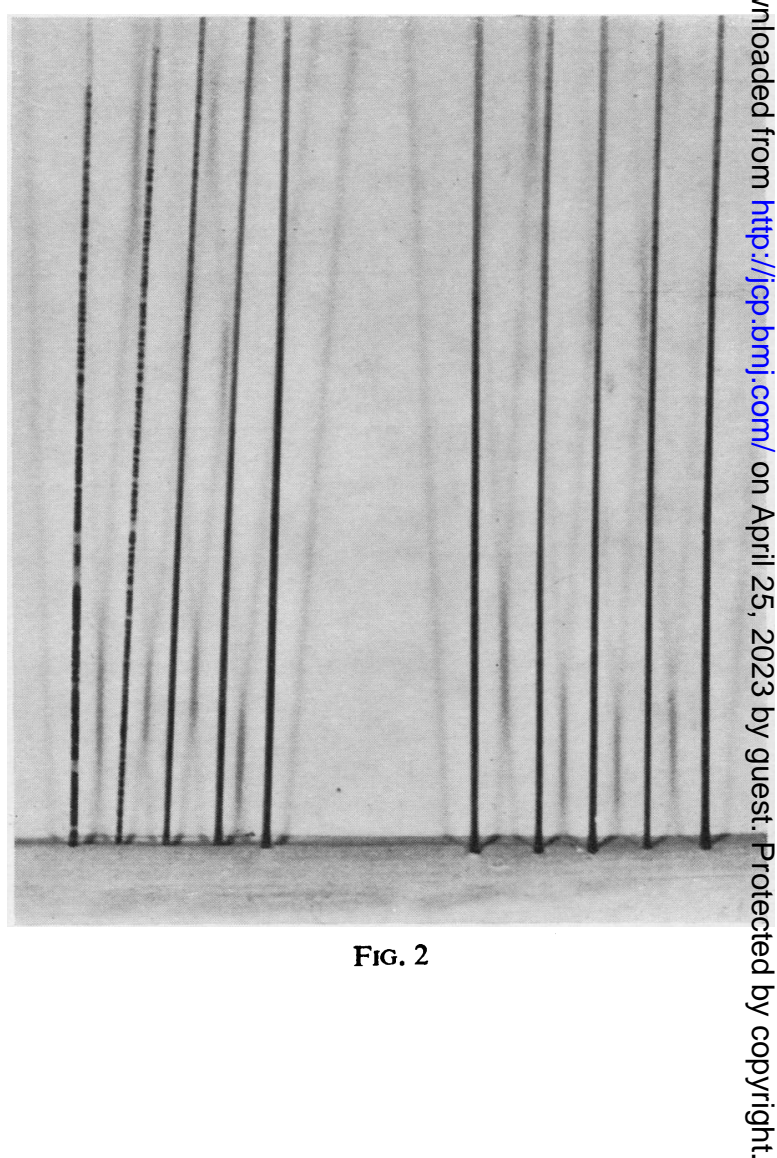


tube was first dipped into the suspension of unsensitized cells until the latter had run up about $2 \mathrm{~cm}$., and then into the first serum dilution $(1: 2)$ until the capillary contained a 9-cm. column of liquid. This tube served as a control against the possible (though very unlikely) presence in a serum of " cold " agglutinins or iso- or immune-agglutinins against the natural blood group antigens of the test cells. The test proper was done in the same way using sensitized cells. The lower end of each capillary was stuck at an angle of $45^{\circ}$ into a strip of plasticine mounted on a holder made of white perspex which could be stood upside down without disturbing the tubes (Fig. 1). The holder, complete with capillaries, was placed in the $37^{\circ} \mathrm{C}$. incubator, and after about eight minutes, the time required for the first sedimentation of the red cells, it was inverted. The readings were taken after a quarter of an hour's incubation, agglutination being indicated by delayed sedimentation together with a characteristic and unmistakable segmentation of the column of cells: a negative result was noted when the cells fell rapidly, leaving a smooth unbroken "tail" above the main mass (Fig. 2). Further incubation up to an hour, with repeated inversion of the holder, showed no increase in titre with 10 positive sera of different titres and was not therefore carried out as a routine.

\section{Experimental Findings}

Altogether 471 sera, 223 from tuberculous patients and 248 from controls, were tested. None agglutinated the control unsensitized cells, nor was suspensioninstability of sensitized cells found to occur.

"Old Tuberculin" as a Sensitizing Agent.-The sera from 66 patients with pulmonary tuberculosis and 89 hospital in-patients admitted for other conditions were tested using cells sensitized with "old tuberculin" (Burroughs Wellcome), and the results are shown in Table $I$. The difference between the two sets of patients is statistically significant, and when the higher titres are considered the significance

TABLE I

Agglutination Titres of 155 Human Sera using Old Tuberculin (H 37)

\begin{tabular}{|c|c|c|c|c|c|c|c|}
\hline \multirow[b]{2}{*}{ Sera } & & \multirow[b]{2}{*}{$\begin{array}{l}\text { Number } \\
\text { Tested }\end{array}$} & \multirow[b]{2}{*}{ Negative } & \multicolumn{4}{|c|}{ Positive at Serum Dilutions } \\
\hline & & & & $1 / 2$ & $1 / 4$ & $1 / 8$ & $\begin{array}{c}1 / 16 \\
\text { or Over }\end{array}$ \\
\hline Tuberculous & .. & 66 & $15(23 \%)$ & $19(29 \%)$ & $14(21 \%)$ & $11(17 \%)$ & $7(10 \%)$ \\
\hline Control & $\ldots$ & 89 & $51(57 \%)$ & $27(31 \%)$ & $8(9 \%)$ & - & $3(3 \%)$ \\
\hline
\end{tabular}

is greater. However, about one-third of the control sera were positive at a titre of 2 and some at 4 . The results obtained suggest that agglutination of the sensitized red cells is due to antibodies to the tubercle bacillus but that other non-specific factors may also cause the reaction. Thus a test based on this technique and using this "old tuberculin" is of little value for diagnosis.

The Role of Tuberculo-proteins.-Since the majority of the control patients referred to in Table I were Mantoux-positive, the possibility was considered that the false positive findings might be due to the action of a circulating antibody against the tuberculo-proteins responsible for the tuberculin reaction. An attempt 
was therefore made to sensitize red cells with the purest available tuberculo-protein, namely "tuberculin P.P.D." Twenty-three sera from non-tuberculous individuals were tested, of whom 12 were Mantoux-negative and 11 Mantoux-positive. Since few of the sera in this series reacted at $1: 2$ dilution, they were tested undiluted. These sera were similarly tested against cells sensitized with C.C.F. (H 37) and a fair agreement was found in both groups: 10 out of 13 sera of the Mantoux-negative group failed to react with both kinds of sensitized cells, and eight out of 10 in the Mantoux-positive group agglutinated both types of cells. This suggests that the reaction obtained with P.P.D. cells is due to carbohydrate impurities in the sensitizing agent. Carbohydrates are known to be present as impurities to an appreciable extent even in this purified tuberculin (Green, 1946). Thus, tuberculo-proteins do not appear to contribute to the agglutinability of these red cells. Moreover, since some of the sera of Mantoux-negative individuals gave agglutination when undiluted, the testing of undiluted sera was felt to serve no useful purpose and was discontinued.

Preliminary Tests with a Polysaccharide Fraction.-A larger series of tests was carried out using cells which had been treated with the crude polysaccharide fraction (C.C.F. H 37). Two hundred and ninety-five sera were tested, and the results are shown in Table II. These sera were again obtained from patients suffering from

TABLE II

agglutination Titres of 295 Human Sera using C.C.F. (H 37)

\begin{tabular}{|c|c|c|c|c|c|c|c|}
\hline \multirow{2}{*}{ Sera } & & \multirow{2}{*}{$\begin{array}{l}\text { Number } \\
\text { Tested }\end{array}$} & \multirow{2}{*}{ Negative } & \multicolumn{4}{|c|}{ Positive at Serum Dilutions } \\
\hline & & & & $1 / 2$ & $1 / 4$ & $1 / 8$ & $\begin{array}{c}1 / 16 \\
\text { or Over }\end{array}$ \\
\hline Tuberculous & .. & 134 & $58(43 \%)$ & $31(23 \%)$ & $20(15 \%)$ & $12(9 \%)$ & $13(10 \%)$ \\
\hline Control & $\ldots i$ & 161 & $148(92 \%)$ & $4(2.4 \%)$ & $5(3 \%)$ & $1(0.6 \%)$ & $3 *(2 \%)$ \\
\hline
\end{tabular}

* Two of these patients were later found to be tuberculous; the third could not be followed up.

pulmonary tuberculosis, the controls being hospital in-patients with other diseases. Control and "positive" sera were tested in a random way to obviate any bias on the part of the observer. The table shows that there is an even greater contrast between the two groups of patients than in Table I, as nine-tenths of the control sera were negative at $1: 2$ dilutions, whereas over half of the tuberculous were positive at this level. Again, the difference between the groups is accentuated in the higher dilutions. As a result of these serological findings the clinical state of the three control patients giving agglutinin titres of 16 was investigated, two tuberculous lesions being found. One man, admitted for operative correction of strabismus, had a tuberculous cavity at the right lung apex, of low-grade activity. The second patient had long-standing sacro-iliac tuberculosis. The third patient had unfortunately been discharged after minor surgery and has not since been available for follow-up.

Three points were noted at this stage: first, that sera in the control series taken from the Wassermann rack after inactivation were usually completely negative; 
secondly, that control sera tested very soon after taking gave an unduly high proportion of positive results, though to low titres only ; and thirdly, following this line of thought, that a few of the known positive sera showed no appreciable loss of titre after heating at $56^{\circ} \mathrm{C}$. for as long as 75 minutes. It seemed possible that there might be a heat labile component in human sera producing non-specific agglutination.

The Effect of Heating Sera.-Each of 25 untested sera from tuberculous patients and of 25 control sera were divided into two portions of which one was heated at $56^{\circ} \mathrm{C}$. for 30 minutes. Table III shows that, when both portions of all the sera

TABLE III

Comparison of Agglutination Titres of Unheated and Heated Sera

\begin{tabular}{l|l|c|c|c|c|c}
\hline & \multirow{2}{*}{ Negative } & \multicolumn{4}{|c}{ Positive at Serum Dilutions } \\
\cline { 3 - 7 } & & $1 / 2$ & $1 / 4$ & $1 / 8$ & $\begin{array}{c}1 / 16 \\
\text { or Over }\end{array}$ \\
\hline $\begin{array}{c}25 \text { sera from tuber- } \\
\text { culous patients }\end{array}$ & Unheated & - & $1(4 \%)$ & $4(16 \%)$ & $6(24 \%)$ & $14(56 \%)$ \\
\cline { 2 - 7 } & Heated & $2(8 \%)$ & $11(44 \%)$ & $7(28 \%)$ & $1(4 \%)$ & $4(16 \%)$ \\
\hline $\begin{array}{c}25 \text { sera from control } \\
\text { patients }\end{array}$ & Unheated & $16(64 \%)$ & $2(8 \%)$ & $5(20 \%)$ & $2(8 \%)$ & - \\
\cline { 2 - 7 } & Heated & $20(80 \%)$ & $5(20 \%)$ & - & - & - \\
\hline
\end{tabular}

were tested with the same batch of cells treated with C.C.F. (H 37), the number of false positives fell by nearly half, and none were observed at titres higher than 2 in this small control group. There must also have been a non-specific thermo-labile element in a proportion of the tuberculous sera, since there is some fall in their titre after heating. However, the difference between the control and the tuberculous groups seems to be still further accentuated by heating.

The Findings with Freshly Drawn Sera.-Another anomaly observed was that when approximately half of a batch of tuberculous sera were tested on the day of taking and the remainder tested two days later, after storage at just above freezingpoint, the second group gave lower agglutination titres and a higher proportion of negative results than was likely to be due to an error of sampling: it seemed that an appreciable deterioration of the sera had occurred with keeping in the unfrozen state. Tests were carried out based on the above findings. One hundred and twenty-six sera were investigated, 66 from tuberculous patients substantially similar to those in the various tests above, and 60 controls. Twenty-three of the latter were from hospital in-patients considered to be free from tuberculosis, and 37 were from nurses and medical students, clinically and radiologically healthy. After the minimum time had been allowed for the separation of the clot, each serum was immediately placed in the freezing compartment of a refrigerator. Tests using cells treated with C.C.F. (H 37) were immediately preceded by heating and thawing of the sera at $56^{\circ} \mathrm{C}$. for 30 minutes. The results are presented in Table IV, and arbitrary plus signs have been allotted to the serum dilutions in an attempt to indicate the clinical 
TABLE IV

Agglutination Titres of 126 Fresh Human Sera (Inactivated) using C.C.F. (H 37)

\begin{tabular}{|c|c|c|c|c|c|c|c|}
\hline Sera & & $\begin{array}{l}\text { Number } \\
\text { Tested }\end{array}$ & Negative & $\begin{array}{c}\stackrel{ \pm}{ \pm} \\
\text { (Positive } \\
\text { at } 1 / 2 \text { ) }\end{array}$ & $\begin{array}{c}+ \\
\text { (Positive } \\
\text { at } 1 / 4)\end{array}$ & $\begin{array}{c}++ \\
\text { (Positive } \\
\text { at } 1 / 8)\end{array}$ & $\begin{array}{c}+++ \\
\text { (Positive at } \\
1 / 16 \text { or Over) }\end{array}$ \\
\hline Tuberculous & .. & 66 & $5(7.6 \%)$ & $17(25.8 \%)$ & $18(27.2 \%)$ & $15(22.7 \%)$ & $11(16.7 \%)$ \\
\hline Control & .. & 60 & $40(66.7 \%)$ & $15(25.0 \%)$ & $5 \quad(8.3 \%)$ & - & - \\
\hline
\end{tabular}

value of the test. Thus, it appears that the test would give reliable results at the 2-plus or higher levels, but the number of positives recovered is only one-third of the patients.

Correlation with Sedimentation Rates.-It was thought that these findings might be correlated with the sedimentation rates of the tuberculous patients. Fig. 3 is a "dot" diagram relating agglutination titres in 118 patients with their Westergren sedimentation rates: no correlation was observed.

Correlation with the Duration of Disease.-Another possibility was that longstanding disease might give rise to higher titres than more recent infections, and

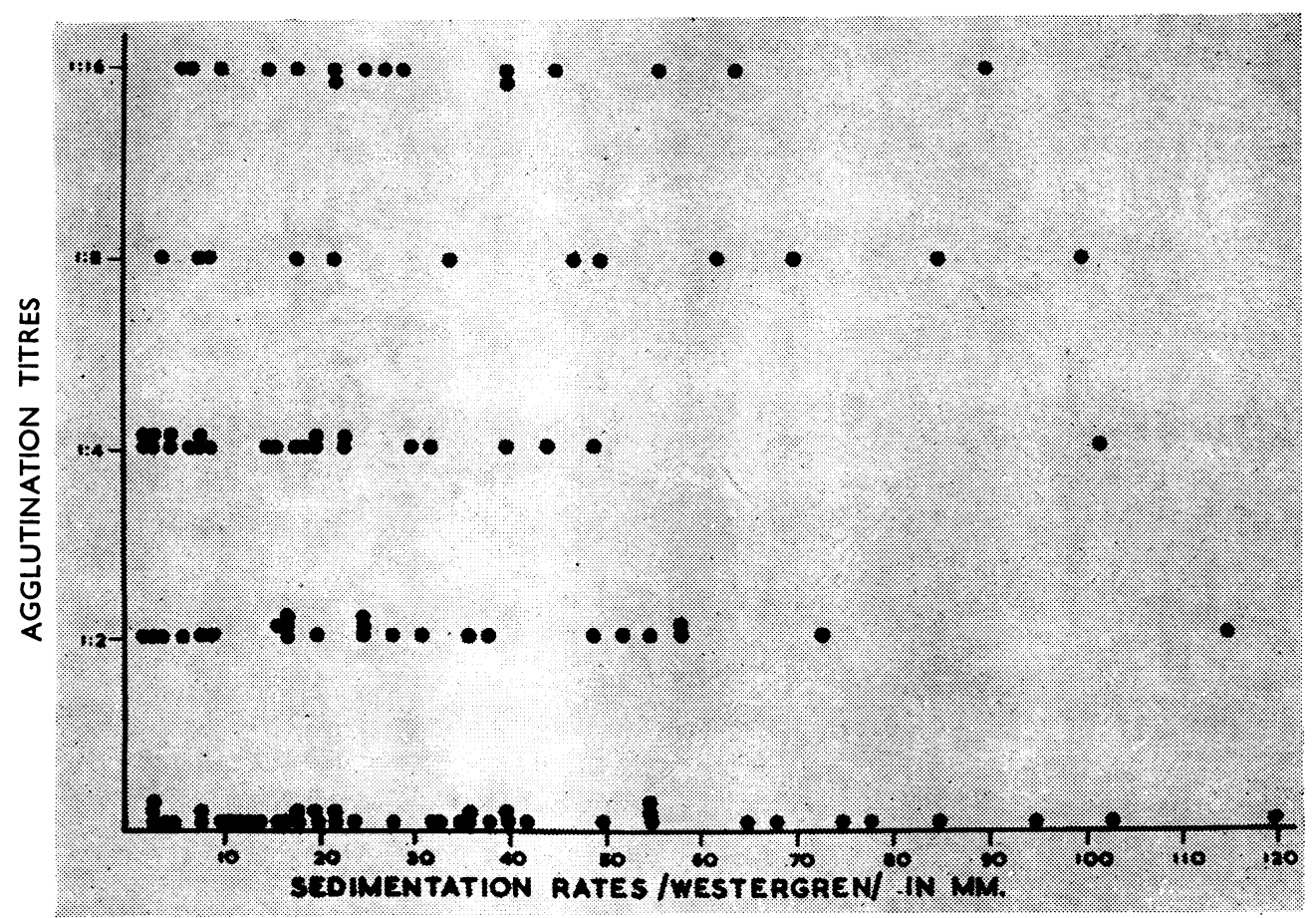

FIG. 3.-Correlation between agglutination titres and sedimentation rates. 
Fig. 4 shows in "dot" form the relation between observed titres and duration of disease in 122 patients. It can be seen that higher titres were obtained with sera from those with disease of longer duration, but nevertheless there were many such that failed to show a significant titre. Most of the patients had been ill for six months to four years.

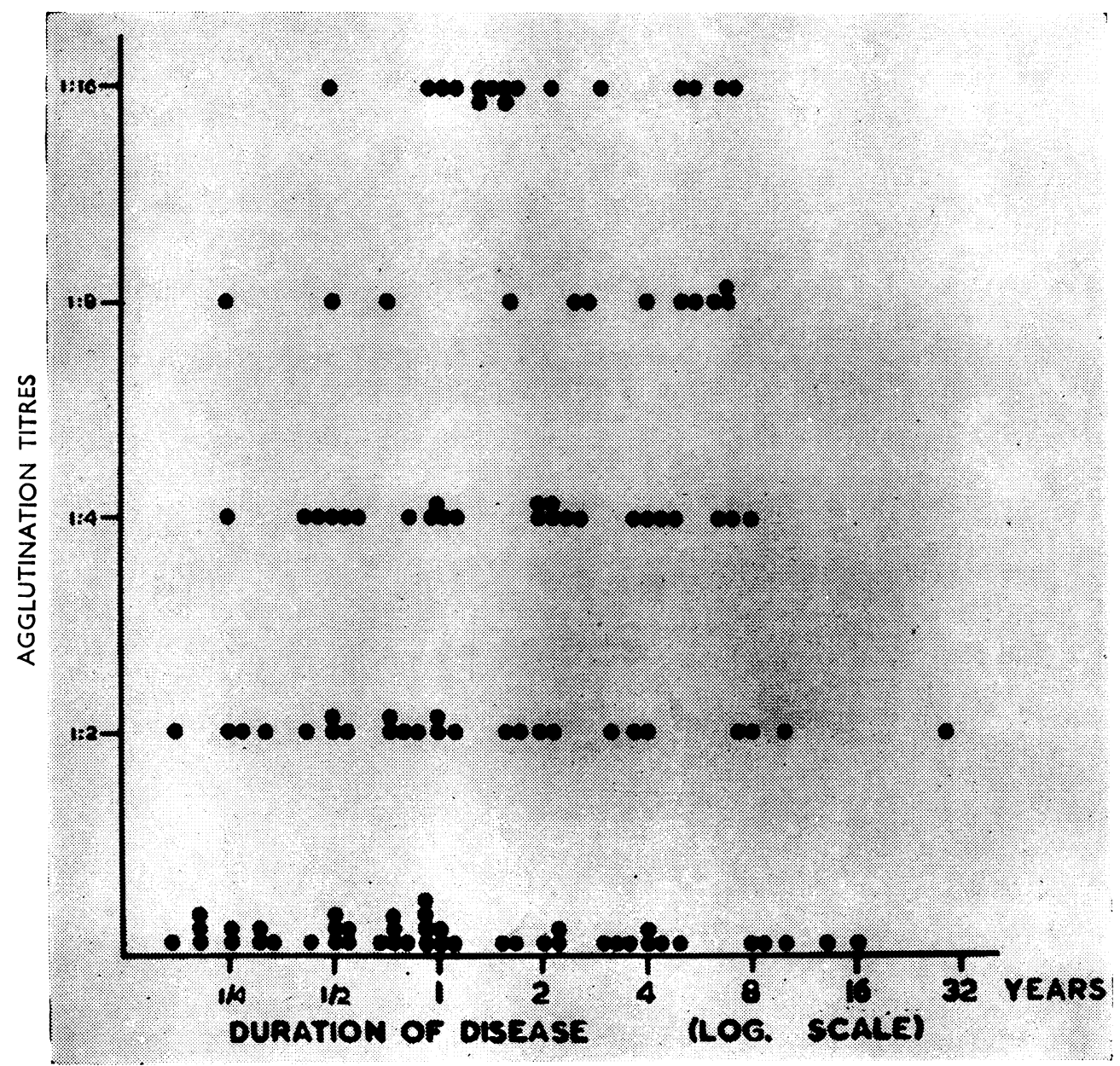

FIG. 4.-Correlation between agglutination titre and duration of disease.

The Use of Polysaccharides from Different Strains. - Since many of the sera from tuberculous patients failed to react in a significant titre (i.e., $1: 8$ or over), it seemed possible that the organism used for sensitization might not be antigenically representative of all infecting strains. The exact nature of the sensitizing agent in the crude fraction used here is not known, therefore it is impossible to assess the probability of such an antigenic difference. Similar crude polysaccharide fractions were 
TABLE V

Comparison of Titres of 61 Human Sera Tested with Sensitizing Agents Obtained FROM THREe MAMMALIAN STRAINS

\begin{tabular}{|c|c|c|c|c|}
\hline & $\begin{array}{l}\text { Serum } \\
\text { No. }\end{array}$ & $\begin{array}{l}\text { Titres with } \\
\text { "H 37" } \\
\text { Cells }\end{array}$ & $\begin{array}{l}\text { Titres with } \\
\text { "NTC 913" } \\
\text { (Bovine) Cells }\end{array}$ & $\begin{array}{l}\text { Titres with } \\
\text { "NTC 276" } \\
\text { (Human) Cells }\end{array}$ \\
\hline $\begin{array}{l}\text { Agglutination titres of } 36 \\
\text { sera from tuberculous } \\
\text { patients }\end{array}$ & $\begin{array}{l}526 \\
506 \\
507 \\
522 \\
502 \\
512 \\
526 \\
509 \\
505 \\
504 \\
510 \\
525 \\
523 \\
519 \\
549 \\
550 \\
537 \\
548 \\
520 \\
524 \\
544 \\
540 \\
533 \\
536 \\
521 \\
516 \\
513 \\
517 \\
514 \\
501 \\
518 \\
515 \\
503 \\
511 \\
508\end{array}$ & $\begin{array}{r}\overline{16} \\
8 \\
8 \\
16 \\
8 \\
4 \\
16 \\
4 \\
4 \\
16 \\
4 \\
4 \\
4 \\
4 \\
4 \\
4 \\
2 \\
8 \\
8 \\
2 \\
4 \\
4 \\
2 \\
4 \\
- \\
\\
2 \\
4 \\
2 \\
16\end{array}$ & $\begin{array}{r}-8 \\
8 \\
8 \\
8 \\
4 \\
2 \\
8 \\
4 \\
4 \\
8 \\
4 \\
2 \\
2 \\
2 \\
-1 \\
4 \\
4 \\
4 \\
2 \\
4 \\
\\
2 \\
\\
\\
\\
2 \\
2 \\
2 \\
16\end{array}$ & $\begin{array}{r}\overline{16} \\
8 \\
8 \\
16 \\
8 \\
4 \\
8 \\
4 \\
4 \\
16 \\
8 \\
2 \\
4 \\
4 \\
4 \\
2 \\
4 \\
2 \\
8 \\
8 \\
2 \\
4 \\
2 \\
4 \\
2 \\
- \\
2 \\
2 \\
4 \\
16\end{array}$ \\
\hline $\begin{array}{l}\text { Agglutination titres of } 25 \\
\text { control sera }\end{array}$ & $\begin{array}{l}499 \\
493 \\
459 \\
451 \\
470 \\
494 \\
551 \\
462 \\
555 \\
500 \\
466 \\
557 \\
553 \\
471 \\
458 \\
554 \\
454 \\
464 \\
491 \\
453 \\
465 \\
463 \\
498 \\
495 \\
496\end{array}$ & $\begin{array}{l}\frac{2}{2} \\
4 \\
2 \\
= \\
= \\
= \\
\overline{-} \\
\frac{2}{2} \\
\frac{4}{4} \\
\frac{-}{4} \\
\frac{2}{2} \\
\frac{2}{2}\end{array}$ & $\begin{array}{l}\bar{Z} \\
2 \\
4 \\
2 \\
\bar{Z} \\
\bar{Z} \\
\bar{Z} \\
\bar{Z} \\
2 \\
\frac{4}{2} \\
\bar{Z} \\
\overline{2} \\
\bar{Z}\end{array}$ & $\begin{array}{l}\bar{Z} \\
2 \\
4 \\
4 \\
\bar{Z} \\
\bar{Z} \\
\overline{-} \\
\overline{2} \\
\frac{4}{2} \\
\overline{2} \\
\overline{2} \\
\bar{Z} \\
\overline{2}\end{array}$ \\
\hline
\end{tabular}


prepared from two other commercial "old tuberculins" (derived from human strain N.C.T.C. 276 and from bovine strain N.C.T.C. 913). These two extracts, and that from the $\mathrm{H} 37$ strain, were used to sensitize red cells, which were then tested against 69 human sera (Table V).

In addition, three other strains of human type ("DT," "PN," and " $C$ ") and an avian strain were extracted. These strains were obtained in the form of a wet bacterial mass, and the mode of preparation of the extracts is described in the technical methods. This technique was used because it yielded material which appeared to react in a way similar to that obtained from old tuberculins. Three of these extracts were compared with that from H 37 O.T. using 50 human sera (Table VI). The fourth extract from human strain "C," tested with a smaller number of sera, behaved similarly. It appears from these results and from Table V that none of the newer extracts was more specific than that of the $\mathrm{H} 37$ or tuberculin from the point of view of a sero-diagnostic test. Furthermore, there was no obvious indication of strain variation, except that the avian extract apparently lacked the specific principle and did not render the cells susceptible to agglutination by human sera.

\section{Discussion}

As the "old tuberculin" used by the American authors was not available, the results here are not strictly comparable with their findings. It appeared reasonable to investigate the separate effects of the protein and polysaccharide constituents of tuberculin. The essentially negative findings with P.P.D. suggest that either tuberculoproteins do not adhere sufficiently to the red cells, or that no specific antibody was present in the sera tested. On the other hand, it is clear that the alcohol-precipitable fraction of protein-free tuberculin contains a specific sensitizing factor. In this connexion, it was noted that the serum of one of 16 Mantoux-negative persons was positive to a titre of 2. This finding agrees with those of Smith and Scott (1950), who showed that the serum of one out of 23 Mantoux-negative students gave a positive reaction, while after Mantoux testing five were positive. They argued that the skin-test itself stimulated antibody production, and, confirming this, found that of 58 tuberculin-positive students 12 gave positive haemagglutination reactions before, and 27 after, the Mantoux test. Positive results were also found in a small number of B.C.G.-treated individuals. It is not known whether antibody titres detected by this test appear before the skin reaction becomes positive at the time of primary infection, or if very high titres occur then: further work is needed on these points, as well as on the behaviour of the test during vaccination with B.C.G. or the vole bacillus.

Since the complement fixation reaction for tuberculosis has been found to give cross reactions with syphilitic sera, nine Wassermann-positive sera were tested by the method and found to be completely negative. This result agrees with the findings of Middlebrook and Dubos (1948) and of Rothbard et al. (1950), who found no higher incidence of positive reactions in syphilitic sera than in their general series of non-tuberculous controls.

It seems paradoxical that heating sera appears to increase the specificity of the test, while the keeping of sera in the unfrozen state leads to loss of potency. It is 
TABLE VI

Comparison of Titres of 50 Human Sera Tested with Sensitizing Agents from an AVian and Three Human Strains

\begin{tabular}{|c|c|c|c|c|c|}
\hline & $\begin{array}{c}\text { Serum } \\
\text { No. }\end{array}$ & $\begin{array}{l}\text { Titres with } \\
\text { "H 37" } \\
\text { Cells }\end{array}$ & $\begin{array}{l}\text { Titres with } \\
\text { "DT" } \\
\text { Cells }\end{array}$ & $\begin{array}{l}\text { Titres with } \\
\text { "PN" } \\
\text { Cells }\end{array}$ & $\begin{array}{l}\text { Titres with } \\
\text { Avian } \\
\text { Cells }\end{array}$ \\
\hline $\begin{array}{l}\text { Sixteen sera from tuber- } \\
\text { culous patients showing } \\
\text { titre variation of no signi- } \\
\text { ficance }\end{array}$ & $\begin{array}{r}6 \\
8 \\
9 \\
13 \\
14 \\
16 \\
19 \\
20 \\
25 \\
26 \\
27 \\
35 \\
36 \\
37 \\
39 \\
40\end{array}$ & $\begin{array}{r}2 \\
2 \\
16 \\
8 \\
4 \\
16 \\
2 \\
4 \\
4 \\
16 \\
16 \\
8 \\
8 \\
8 \\
8\end{array}$ & $\begin{array}{r}4 \\
2 \\
16 \\
4 \\
4 \\
16 \\
4 \\
4 \\
2 \\
16 \\
16 \\
4 \\
2 \\
8 \\
8 \\
16\end{array}$ & $\begin{array}{r}4 \\
4 \\
16 \\
8 \\
8 \\
16 \\
4 \\
8 \\
4 \\
16 \\
16 \\
4 \\
2 \\
16 \\
8 \\
16\end{array}$ & $\begin{array}{l}= \\
= \\
= \\
= \\
= \\
= \\
= \\
= \\
=\end{array}$ \\
\hline $\begin{array}{l}\text { (Total 25) } \\
\text { Nine sera from tuberculous } \\
\text { patients showing titre } \\
\text { variation of doubtful signi- } \\
\text { ficance }\end{array}$ & $\begin{array}{r}1 \\
4 \\
5 \\
7 \\
15 \\
17 \\
29 \\
32 \\
33\end{array}$ & $\begin{array}{c}4 \\
8 \\
8 \\
4 \\
4 \\
4 \\
2 \\
2\end{array}$ & $\begin{array}{r}-4 \\
4 \\
16 \\
2 \\
4 \\
8 \\
2\end{array}$ & $\begin{array}{r}4 \\
16 \\
16 \\
16 \\
4 \\
8 \\
16 \\
8 \\
8\end{array}$ & $\begin{array}{l}z \\
z \\
z \\
z \\
z\end{array}$ \\
\hline $\begin{array}{l}\text { Eighteen control sera show- } \\
\text { ing titre variation of no } \\
\text { significance }\end{array}$ & $\begin{array}{r}10 \\
2 \\
11 \\
12 \\
21 \\
22 \\
30 \\
31 \\
34 \\
38 \\
41 \\
42 \\
43 \\
46 \\
47 \\
48 \\
49 \\
50\end{array}$ & $\begin{array}{r}2 \\
- \\
4 \\
2 \\
2 \\
8 \\
2 \\
= \\
= \\
= \\
= \\
- \\
\end{array}$ & $\begin{array}{r}- \\
2 \\
4 \\
2 \\
4 \\
8 \\
4 \\
2 \\
-\bar{E} \\
= \\
= \\
= \\
4 \\
\end{array}$ & $\begin{array}{r}2 \\
\frac{2}{4} \\
4 \\
4 \\
16 \\
4 \\
\frac{2}{2} \\
\frac{2}{2} \\
\frac{-}{4} \\
-\end{array}$ & $\begin{array}{l}= \\
= \\
= \\
= \\
= \\
= \\
= \\
= \\
= \\
=\end{array}$ \\
\hline $\begin{array}{l}\text { Seven control sera showing } \\
\text { titre variation of doubtful } \\
\text { significance }\end{array}$ & $\begin{array}{r}3 \\
18 \\
23 \\
24 \\
28 \\
44 \\
45\end{array}$ & $\begin{array}{l}8 \\
2 \\
4 \\
2 \\
4 \\
2 \\
-\end{array}$ & $\begin{array}{r}4 \\
2 \\
16 \\
16 \\
4 \\
4 \\
4 \\
2\end{array}$ & $\begin{array}{r}16 \\
8 \\
8 \\
8 \\
16 \\
8 \\
4\end{array}$ & $\begin{array}{l}\overline{-} \\
\bar{z} \\
\bar{z}\end{array}$ \\
\hline
\end{tabular}


known, however, that Rhesus antisera of human origin deteriorate if not frozen solid (Mollison, Mourant, and Race, 1948 ; Stirk, 1950), and it seemed likely that the tuberculous antibody behaved similarly. A further similarity found was that one sample of high titre Rhesus antiserum (saline anti-D agglutinin titre 128) showed no diminution in titre when tested by the standard method before and after heating at $56^{\circ} \mathrm{C}$. for 30 minutes. It may be that the observed loss of titre of human sera on keeping is due to the action of a proteolytic enzyme active at about $4^{\circ} \mathrm{C}$.

It must be admitted, however, that, when due allowance has been made for the technical difficulties enumerated above, the test from the clinical standpoint still leaves much to be desired. Two main problems arise: first, what significance should be attached to the existence in the sera of normal individuals of antibodies to an extract of tubercle bacilli ; and secondly, why do the sera of about two-thirds of patients suffering from active tuberculosis fail to give significant titres with this test ?

Tuberculosis differs from such diseases as syphilis, in which serological tests are of proved value. Relatively few people become syphilitic, and the finding of a positive reaction to a sero-diagnostic test is generally accepted as evidence of infection, but in tuberculosis most of the members of a community become infected, and, of these, the greater number rapidly overcome the infection. It is therefore not surprising to find tuberculous antibodies in low titre in the sera of normal individuals ; in addition, such titres may reach higher levels after secondary subclinical stimulations. Thus, in the evaluation of this test, it is necessary to set an arbitrary dividing line based on a sufficient number of tests, titres below the chosen level occurring in healthy individuals, and those above this line being associated with clinical disease only. It thus appears that an arbitrary division might be set in this test at, or just below, a titre of 8 ; this is not, however, entirely satisfactory, in that only about one-third of the sera from tuberculous patients in our series were positive at this level. There are four possible explanations of this failure to obtain significant titres. The first is that the extract used for most of the tests is not sufficiently representative, and this aspect has been discussed above. On the limited evidence presented in Tables V and VI this does not appear a likely explanation, since the variations in titre amongst the different mammalian strains are not significant. A more decisive inquiry into this problem would consist of the isolation and extraction of organisms from "false negative" cases and the testing of such extracts with the patients' sera.

The second possible explanation for failure to detect antibodies is that, although they are being formed, there is liberation of an excess of bacillary products capable of reacting in vivo with the antibodies so that detection of the latter in vitro is precluded. This hypothesis of "swamping" might be investigated, as it is known that minute quantities of the sensitizing reagent in solution effectively block the reaction (Middlebrook and Dubos, 1948), and it would not be difficult to apply this method to "false negative" sera. Further consideration, however, suggests that the sensitizing factors might adhere to the patient's own red cells and thus be removed from the serum.

The third explanation for the failure is that antibodies were not present at the time of testing since they may not have been formed or may have been removed 
by some mechanism other than that considered in the preceding paragraph. It is well known that the maintenance of antibody levels in infectious disease is dependent on continuous or repeated antigenic stimulation. For the purposes of this test it seems likely that the access of the breakdown products of tubercle bacilli to the blood stream is of greater importance than the nature and extent of the anatomical lesion (Middlebrook, 1950). It must not be assumed, however, that the findings with this test are any indication of a patient's state of immunity, or even an indication that protective antibodies are present or absent. In the haemagglutination reaction a deliberate selection of part of the breakdown products of tubercle bacilli has been made: a part which is capable of adhering to red cells. Protective antibodies, if formed, may be directed against other bacterial constituents, or even against constituents elaborated in the lesion. The other aspect of this problem is that antibodies formed at an earlier date have disappeared at the time of the test. Clearly the liberation of antigenic material into the circulation ought to be greater from an early or extending lesion than from an older or quiescent one. If this is the case, a close correlation between clinical activity and significant titres is to be expected. The following-up of individual patients should elucidate any variations in titre associated with the progress of disease.

Yet another possibility has to be referred to: failure to detect "incomplete" antibodies of the type encountered in Rhesus work (Wiener, 1944 ; Diamond and Denton, 1945). The examination of a small number of "false negative" sera, diluted with $20 \%$ bovine albumin, was carried out and failed to reveal any agglutination ; further investigation of this point is clearly needed.

In conclusion it may be said that a significant difference in antibody titres can be demonstrated between tuberculous patients and people without clinical tuberculosis. The practical usefulness of the test is limited by the relatively small number of clear-cut reliable positive and the relatively large number of doubtful and "false negative" results. Improvements in technique and repeated examinations may well increase its value. High titres in doubtful clinical conditions where the diagnosis lies between a tuberculous or another aetiology may be a most useful adjunct to diagnosis.

\section{Summary}

It has been shown that red cells can be sensitized with extracts of tubercle bacilli, becoming agglutinable by sera of tuberculous animals and patients. This principle has been used to try to obtain a test of clinical value.

Human Group $O$ red cells were exposed to various extracts of tubercle bacilli, and the washed cells were tested using serial dilutions of human sera and Chown's capillary tube method of agglutination.

Unmodified "old tuberculin" was unsatisfactory as a sensitizing agent. Tuberculo-proteins do not appear to play a role in the reaction. A crude carbohydrate fraction was found to be the most suitable of the products tested.

Uninactivated sera and sera kept unfrozen for any length of time gave anomalous reactions. Fresh sera heated for 30 minutes at $56^{\circ} \mathrm{C}$. and tested against red cells sensitized with a crude carbohydrate fraction obtained from the $\mathbf{H} 37$ strain gave best results. Titres of 8 and over appear to be significantly associated with clinical 
tuberculosis, but occurred in only one-third of the patients tested. Possible explanations for this are discussed, and suggestions are made for further investigations.

We wish to express our sincere thanks to Dr. H. H. Green, of the Veterinary Research Laboratories, Ministry of Agriculture and Fisheries, Weybridge, for-providing valuable materials. Our thanks are also due to various friends who kindly provided sera of tuberculous patients.

\section{REFERENCES}

Diamond, L. K., and Denton, R. L. (1945). J. Lab. clin. Med., 30, 821.

Discombe, G., and Meyer, H. (1948). J. clin. Path., 1, 73.

Gernez-Rieux and Tacquet, A. (1949). Bull. Acad. nat. Méd., Paris, 133, 556.

Green, H. H. (1946). Vet. J., $102,267$.

Middlebrook, G. (1950). Amer. Rev. Tuberc., 62, 223.

and Dubos, R. J. (1948). J. exp. Med., 88, 521.

Mollison, P. L., Mourant, A. E., and Race, R. R. (1948). Med. Res. Coun. Memo., No. 19, p. 58.

Rothbard, S., Dooneief, A. S., and Hite, K. E. (1950). Proc. Soc. exp. Biol., N.Y., 74, 72.

Smith, D. T., and Scott, N. B. (1950). Amer. Rev. Tuberc., 62, 121.

Sohier, R. (1950). Ann. Inst. Pasteur, 78, 283.

Stirk, E. M. (1950). Lancet, 1, 902.

Wieghard, C. W., and Julianelle, L. A. (1935). J. exp. Med., $62,23$.

Wiener, A. S. (1943). Blood Groups and Transfusion, 3rd ed., p. 200, Springfield, Ill. (1944). Proc. Soc. exp. Biol., N.Y., 56, 173.

Wilson, G.S., and Miles, A. A. (1946). Topley and Wilson's Principles of Bacteriology and Immunity, 3rd ed., vol. 2, p. 1323. 